\title{
GC/MS of Volatile Oils and Horticultural Characteristics of Four Curled and Non- Curled Netherlands' Parsley Genotypes Grown under the Conditions of Middle Egypt in Clay Soil for the First Time
}

\author{
Ashraf N. E. Hamed ${ }^{1 *}$, Yasser M. M. Moustafa ${ }^{2}$, Ahmed F. Tawfike ${ }^{3,4}$, Mokhtar M. Bishr ${ }^{5}$, Usama R. \\ Abdelmohsen ${ }^{1,6}$ \\ ${ }^{1}$ Department of Pharmacognosy, Faculty of Pharmacy, Minia University, Minia 61519, Egypt \\ ${ }^{2}$ Horticulture Department, Faculty of Agriculture, Minia University, Minia 61517, Egypt \\ ${ }^{3}$ Department of Pharmacognosy, Faculty of Pharmacy, Helwan University, Cairo, 11795, Egypt \\ ${ }^{4}$ Molecular discovery group, Computational and Analytical Science Department, Rothamsted Research, AL5 2JQ, Harpenden,UK \\ ${ }^{5}$ Research and Development Department, Mepaco Company, Cairo, 11361, Egypt \\ ${ }^{6}$ Department of Pharmacognosy, Faculty of Pharmacy, Deraya University, 61111 New Minia, Egypt
}

Received: July 28, 2020; revised: September 16, 2020; accepted: October 1, 2020

\begin{abstract}
The main aim of this study was to differentiate among four Netherlands' genotypes of parsley (Moskurl 2 Petra, Moskurl 2 KRA USA, Gewone Dai 3 Rial 10 and Bravour) grown under Middle Egypt conditions in clay soil for the first time based on vegetative growth and oil composition. Gewone Dai 3 Rial 10 genotype is non-curly leafed, while the others are curly-leafed varieties. A field experiment was achieved during the two successive winter seasons of 2015/2016 and 2016/2017. This comparative study included horticultural characteristics (e.g. fresh plant weight (g), total yield of fresh leaves (ton/fed), shoot length (cm), total soluble solids (TSS) and leaves water content in addition to the chemical profile of the essential oil. The Gewone Dai 3 Rial 10 genotype showed the highest values of all growth characteristics in the two successive seasons. While, Moskrul 2 Petra gave the highest percentage of myristicin (33.91\%) followed by Moskrul 2 KRA USA (33.22\%), Bravour (29.30\%) and Gewone Dai 3 Rial 10 (28.51\%). While, Moskrul 2 KRA USA gave the highest apiole content (3.52\%). Myristicin and apiole were estimated because of their importance as cancer chemo-preventive agents as well as improving the quality of parsley, which is produced in Egypt. This could also support the Egyptian income from their exportation as dried herb or essential oil or as food supplement or myristicin production.
\end{abstract}

\section{Key words}

GC/MS, Genotypes, Myristicin, Parsley, Petroselinum crispum (Mill.).

\section{Introduction}

Apiaceae (Umbelliferae) family has more than 3.000 species worldwide. Its plants are cultivated for many purposes viz., vegetable crops (i.e. carrots, parsley, parsnip, celery and others not to mention) as well as aromatic and medicinal properties (anise, angelica, caraway, coriander, cumin, dill, fennel, lovage,..etc.). Because of their well-documented health benefits, the usage of these plants is very widespread in everyday diet. Apiaceae is a very essential source of phytoconstituents (phenolic compounds, polyacetylenes, terpenoids,...etc) with various pharmacological activities [1]. One of these plants is parsley (Petroselinum crispum Mill.). It has many synonyms [P. hortense Hoffm., P. sativum Hoff., Carum Petroselinum (L.) Benth. and Hook. F.] [2]. It is a biennial crop, native to Europe and Western Asia and cultivated annually for its aromatic and attractive leaves [3]. The composition of parsley essential oil differs among species and with different climate conditions. Furthermore, the essential oil content may likely vary with the stage of plant development, the cultivation season as well as the part of the plant under analysis [4].

Essential oils are chiefly monoterpenes $\left(\mathrm{C}_{10}\right)$ and sesquiterpenes $\left(\mathrm{C}_{15}\right)$. They are hydrocarbons with molecular formula $\left(\mathrm{C}_{5} \mathrm{H}_{8}\right)_{\mathrm{n}}$. Oxygenated constituents derived from these hydrocarbons include phenols, alcohols, oxides, ethers, ketones, esters and aldehydes. Other compounds comprise phenyl propenes and specific nitrogen or sulphur constituents [5].

Parsley essential oil demonstrated antifungal and antiaflatoxigenic activities against an extremely toxic and carcinogenic mycotoxin (Aflatoxin $\mathrm{B}_{1}$ ), which is produced by Aspergillus flavus. It exhibited a stronger inhibitory effect than Ginger [6]. Furthermore, it improved the toxicological effect of zearalenone mycotoxin [7].

This provoked us to differentiate among four Netherland's parsley genotypes grown under Middle Egypt growing conditions in clay soil for the first time viz., horticultural characteristics and GC/MS of volatile oils. 


\section{Materials and Methods}

\subsection{Plant material}

In the clay soil of the Research Farm, Faculty of Agriculture, Minia University, Minia, Egypt, four genotypes with curled leaves (Moskrul 2 Petra, Moskrul 2 KRA USA and Bravour) and non-curly-leafed (Gewone Dai 3Rial 10) parsley genotypes seeds were imported from Netherlands to be evaluated under Middle Egypt growing conditions. Seeds were obtained from the Bejo Zaden b.v. Trambaan 1, $1749 \mathrm{CZ}$ Warmenhuizen. These seeds were planted in two rows (each row was $35 \mathrm{~cm}$ wide and $350 \mathrm{~cm}$ long) in small plots $(3.0 \mathrm{~m} \mathrm{x} 3.5 \mathrm{~m})$ in two successive winter seasons of 2015/2016 and 2016/2017. All horticultural practices suitable for parsley cultivation and production were followed according to the instructions of the Egyptian Ministry of Agriculture. Three cuttings were taken from the plants, the first one was 65 days after seeding and the second cutting was one month after the first one and also the third cutting was taken one month after the second one. Horticultural data [e.g., fresh plant weight (g), total yield of fresh leaves (ton/fed), shoot length $(\mathrm{cm})$, total soluble solids (TSS) and water content in fresh leaves (\%)] were calculated as average of 10 plants from each replicate were recorded as average of the three cuttings. Fresh plant samples from the four genotypes were taken to the Medicinal and Aromatic Plants Research Department, National Research Center, Cairo, Egypt to obtain the essential oil content and to do the gas chromatography (GC) analysis for the obtained essential oil of all studied samples.

\subsection{Horticultural characteristics}

\subsubsection{Plant fresh weight $(g)$}

All plants previously collected for the three replications of all genotypes were weighed and the average was estimated.

\subsubsection{Total yield of fresh leaves (ton/fed)}

The total yield of fresh leaves was calculated from all plots of all genotypes and then was multiplied in 400 to obtain the total yield ton/fed.

\subsubsection{Shoots length $(\mathrm{cm})$}

Ten plants from all genotypes at the time of cutting were collected for each replication, the shoots lengths were estimated using a ruler and then the average was recorded for the three replicates.

\subsubsection{Total soluble solids (TSS) determination (\%)}

The TSS content in blinded samples was determined according to the official methods of analysis as described in "AOAC" using the handheld refractometer model "FG103/113 measuring range $0 \sim 32 \%$ [8].

\subsubsection{Water content in fresh leaves $(\%)$}

Humidity percentage in fresh parsley plants of all genotypes was calculated as follows:

$$
\text { Humidity } \%=\frac{\text { Plant fresh weight }- \text { plant dry weight }}{\text { Plant fresh weight }} \times 100
$$

The average of ten plants was considered as one replicate and three replicates were recorded for each genotype.

\subsection{GC/MS of volatile oils}

\subsubsection{Preparation of volatile oil}

Each parsley genotype ( $200 \mathrm{~g}$ ) of dried plants was collected and the essential oil was extracted according to Singleton and Rossi [9].

\subsubsection{GC/MS Technique}

\subsubsection{GC Technique}

The column internal diameter was $0.25 \mathrm{~mm}, 30 \mathrm{~m}$ length, packed with Rtx-MS and $0.25 \mu \mathrm{m}$ film thickness. The injected volume was $1 \mu \mathrm{l}$, using helium as carrier gas at flow rate 40 $\mathrm{ml} / \mathrm{min}$. The analysis was carried out at a programmed temperature; the initial temperature was $40{ }^{\circ} \mathrm{C}$ then increased at a rate $30-50{ }^{\circ} \mathrm{C}$ to the final temperature $220^{\circ} \mathrm{C}$ (kept for $5 \mathrm{~min}$ ). The injector and detector had the same temperature of $210^{\circ} \mathrm{C}$. The total run time was $52 \mathrm{~min}$ with a split ratio 1:50.

\subsubsection{Mass analysis}

Total ion chromatograms and mass spectra were recorded in the electron impact ionization mode at $70 \mathrm{eV}$, using ACQ Mode of scan from 35 to $500 \mathrm{~m} / \mathrm{z}$ in $0.3 \mathrm{~s}$.

\section{Results}

\subsection{Horticultural characteristics}

The studied parsley genotypes varied in their growth behavior; the non-curled Gewone Dai 3 Rial 10 showed the biggest size of shoots and Moskurl 2 KRA USA showed the smallest sizes. The other two genotypes showed medium sizes of shoots (Figure 1).

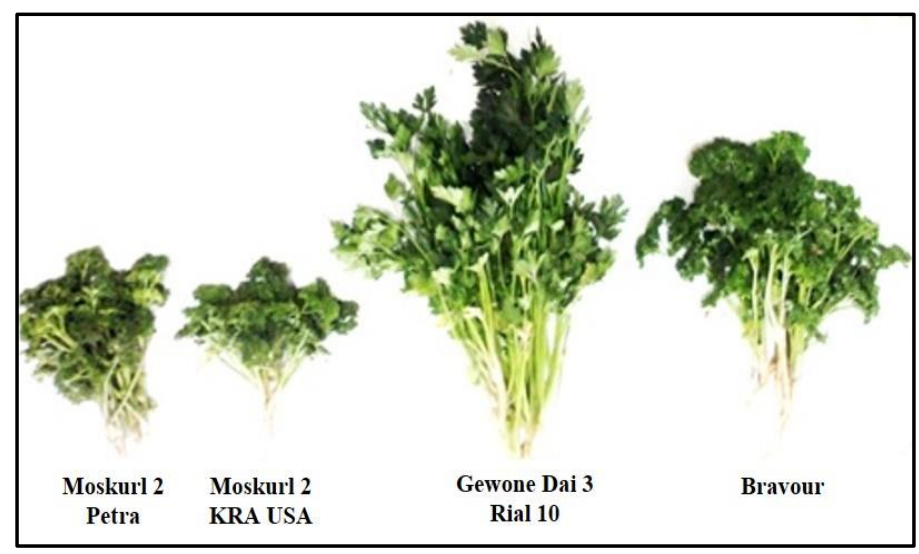

Figure 1: Vegetative growth of the four studied parsley genotypes.

\subsubsection{Plant fresh weight $(g)$}

The Gewone Dai 3 Rial 10 showed the highest values of average fresh weight $(50.9$ and $50.0 \mathrm{~g})$ in the first and second seasons, respectively, while, both Moskrul 2 KRA USA (21.2 and $22.4 \mathrm{~g}$ ) and Bravour (22.8 and $23.7 \mathrm{~g}$ ) gave the lowest values in the same seasons, respectively, (Table 1).

\subsubsection{Total yield of fresh leaves (ton/fed)}

Table (1) showed that the genotype "Gewone Dai 3 Rial 10" produced the highest yield of fresh leaves (as a total of three cuttings) in the two successive seasons (30.4 and 31.4 ton/fed) followed by Moskrul 2 Petra (21.4 and 20.1 ton/fed). While, Bravour (15.7 and 15.0 ton/fed) and Moskrul 2 KRA USA (14.9 
and 14.3 ton/fed)) gave the lowest values of total yield of fresh leaves, respectively.

\subsubsection{Shoot length $(\mathrm{cm})$}

The four studied parsley genotypes varied significantly in their shoot length. Gewone Dai 3 Rial 10 had the longest plants in the two seasons ( 34.3 and $34.6 \mathrm{~cm}$ ) followed by Bravour (22.2 and $22.3 \mathrm{~cm}$ ) and Moskrul 2 Petra (21.1 and $21.7 \mathrm{~cm})$, while, Moskrul 2 KRA USA had the shortest plants $(17.2 \mathrm{~cm}$ in both seasons). The results are demonstrated in Table 1.

\subsubsection{Total soluble solids (TSS) content (\%)}

The TSS content in fresh leaves of all studied genotypes was measured. The data showed that leaves of the genotype Gewone Dai 3 Rial 10 contained the highest values of TSS (6.4 and 6.2 $\%$ ) followed by Moskrul 2 Petra (5.5 and $5.3 \%$ ) in the first and second seasons, respectively. The other two genotypes showed the lowest values. The results are listed in Table 1.

\subsubsection{Water content in fresh leaves $(\%)$}

By determining water content in fresh leaves of the studied parsley genotypes, data showed that leaves of Gewone Dai 3 Rial 10 contained the highest percentages of water (81.5 and $82.5 \%$ ) and those of Bravour contained the lowest percentages (76.6 and $76.0 \%$ ) in the first and second seasons, respectively (Table 1).

\subsection{GC/MS results of parsley genotypes volatile oils}

Identifications of compounds were carried out by direct comparison of retention time and fragmentation patterns with those of reference compounds analyzed under the same conditions. The quantitation was based on peak area integration [10-12]. The results were displayed in Figure 2 and Tables ( $2 \&$ $3)$.

\section{Discussion}

Leafy vegetables play vital roles in food security and alleviate hunger and that is why they are very necessary in the human diet. They are valuable resources of nutrients, where they contribute significantly to fibers, vitamins, proteins, minerals and other nutrients, which they are usually in short supply in daily diets [13].

Moreover, vegetables afford little dietary energy, making them valuable in energy-limited diets. The fiber content has been reported to have beneficial effects on blood cholesterol and helps in the prevention of large intestine diseases, while they improve glucose tolerance in diabetes [14].

Parsley is an important culinary herb native to the Mediterranean area. It has been employed in the pharmaceutical, perfume, cosmetic and food industries. It has small and dark seeds with apiin glycoside [15]. It has been reported to have various pharmacological activities viz., antioxidant [16], antihepatotoxic, anticoagulant, antihyperlipidemic [17], antimicrobial [18], antianemic, menorrhagic [19] and laxative [20]. It has been used traditionally to treat eczema, knee ache, impotence, lumbago, as a blood pressure regulator and nose bleeding [21].

In the current study, the four imported parsley genotypes varied in their growth behavior, the yield of fresh leaves and essential oil yield. The non-curled genotype (Gewone Dai 3 Rial 10) gave the highest yield from fresh leaves. This is very preferred in the Egyptian market as Egyptian people demand non-curled fresh leaves of parsley. This means the non-curled imported genotype "Gewone Dai 3 Rial 10" will be used the same way as the fresh green leaves along with the dried leaves product for exportation. The other curly-leafed genotypes are very promising in parsley exportation as dried leaves, which will be very profitable for Egyptian parsley growers. New genotypes and hybrids introduction to different environments and adaptation to new environmental conditions is very beneficial in crops breeding [22].

In this study, Moskrul 2 Petra genotype gave the highest percentage of myristicin $(33.91 \%)$, which is higher than other species $P$. crispum L. [23], followed by Moskrul 2 KRA USA (33.22\%), Bravour (29.30\%), Gewone Dai 3 Rial 10 (28.51\%), while Gewone Dai 3 Rial 10 genotype displayed the lowest concentration. On the other hand, Moskrul 2 KRA USA gave the highest apiole content (3.52\%). The curled genotype (Moskrul 2 Petra) gave the highest yield of myristicin as shown in Tables 2 and 3. These results are consistent with the previous study in sandy soil [22]. This means both sandy and clay soils give nearly the same production of parsley as well as its oil contents.

Myristicin [1,3-benzodioxole, 4-methoxy-6-(2-propenyl)] had a great importance as an inducer of the detoxifying enzyme glutathione S-transferase (GST) in the liver and small intestine mucosa of mice [24].

The parsley volatile extract demonstrated a higher antioxidant activity (DPPH) than the parsley ethanol extract due to the presence of the dominant phenolic compounds namely, myristicin and apiole. They could be the major contributor to the antioxidant activity. Furthermore, the antifungal and aflatoxin inhibition efficacy of volatile oils may be attributable to the oil compositions. This result may be explained by the high content of some of these substances in the essential oils of parsley [6]. Apiole and myristicin induced significant cytotoxic activity against a group of human cancer cell lines (K-562, NCIH460 and MCF-7) [25].

\section{Conclusion}

The planted and horticulturaly evaluated parsley genotypes showed variable characteristics and good yield of fresh and dried leaves. Some of these genotypes have high content of volatile oils as well as high percentage of myristicin, which can be used as cancer chemo-preventive agent and improve the quality of plants produced in Egypt. Therefore, they can increase the Egyptian income by exporting the dried leaves of these genotypes as dried herbs or essential oil or as food supplement or myristicin production.

\section{Conflict of Interests}

The authors declare that there is no conflict of interests regarding this study.

\section{Orcid}

Ashraf N. E. Hamed ${ }^{\text {DD }}$ orcid.org/0000-0003-2230-9909 


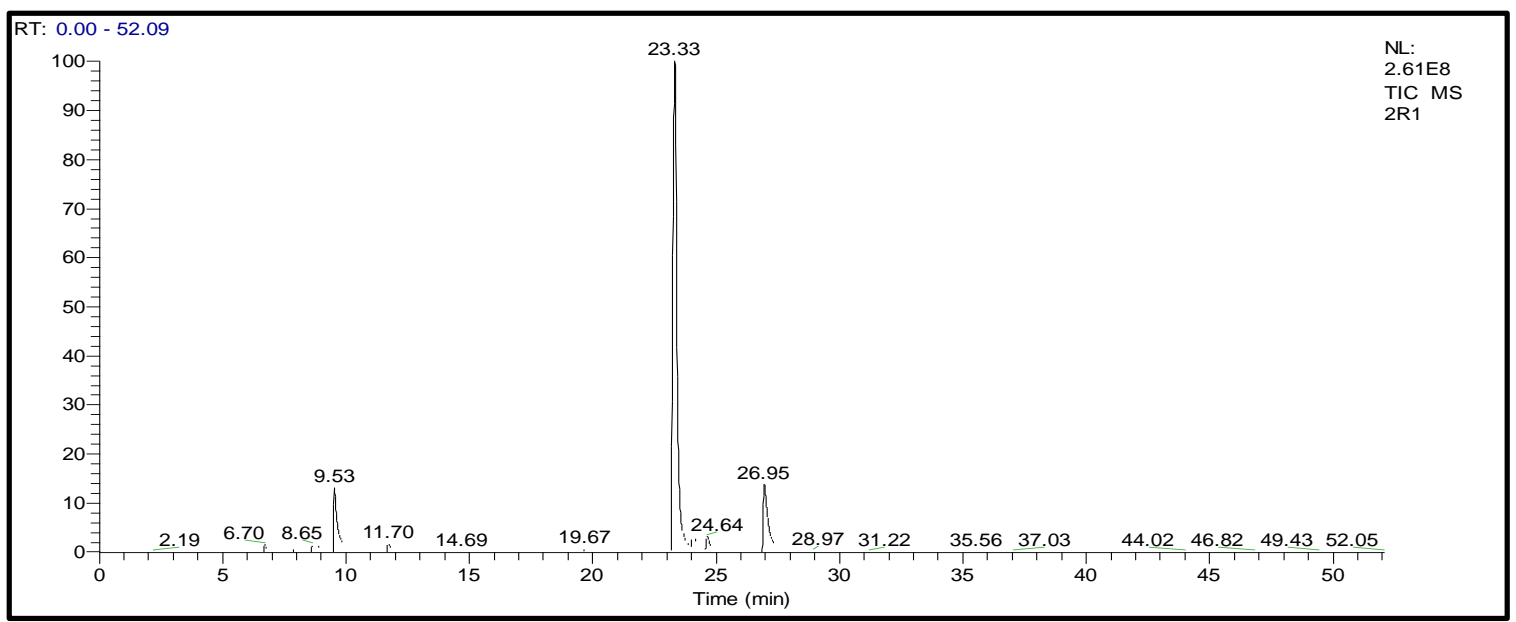

Figure 2: Total ion chromatogram of parsley Moskrul 2 KRA USA.

Table 1: Performance and horticultural characteristics (single plant fresh weight, total yield of fresh leaves, TSS, shoot length and leaves water content) of curled and non-curled (smooth) parsley genotypes planted, adapted and evaluated under the growing conditions of Middle Egypt in clay soil during the two successive winter seasons of 2015/2016 and 2016/2017.

\begin{tabular}{|c|c|c|c|c|c|c|c|c|c|c|}
\hline \multirow{2}{*}{ Genotypes } & \multicolumn{2}{|c|}{$\begin{array}{l}\text { Plant fresh weight } \\
\text { (g) }\end{array}$} & \multicolumn{2}{|c|}{$\begin{array}{l}\text { Total yield of fresh } \\
\text { leaves (ton/fed) }\end{array}$} & \multicolumn{2}{|c|}{$\begin{array}{l}\text { Shoot length } \\
\text { (cm) }\end{array}$} & \multicolumn{2}{|c|}{$\begin{array}{l}\text { TSS } \\
(\%)\end{array}$} & \multicolumn{2}{|c|}{ Leaves water content (\%) } \\
\hline & $\begin{array}{c}\text { First } \\
\text { season }\end{array}$ & $\begin{array}{l}\text { Second } \\
\text { season }\end{array}$ & $\begin{array}{c}\text { First } \\
\text { season }\end{array}$ & $\begin{array}{l}\text { Second } \\
\text { season }\end{array}$ & $\begin{array}{c}\text { First } \\
\text { season }\end{array}$ & $\begin{array}{l}\text { Second } \\
\text { season }\end{array}$ & $\begin{array}{c}\text { First } \\
\text { season }\end{array}$ & $\begin{array}{c}\text { First } \\
\text { season }\end{array}$ & $\begin{array}{c}\text { First } \\
\text { season }\end{array}$ & $\begin{array}{l}\text { Second } \\
\text { season }\end{array}$ \\
\hline Moskrul 2 Petra & $33.3 \pm 1.53$ & $33.7 \pm 1.50$ & $21.4 \pm 0.82$ & $20.1 \pm 1.55$ & $21.1 \pm 0.83$ & $21.7 \pm 0.84$ & $5.5 \pm 0.20$ & $5.5 \pm 0.20$ & $78.3 \pm 0.61$ & $79.0 \pm 0.8$ \\
\hline Moskrul 2 KRA USA & $21.2 \pm 1.52$ & $22.4 \pm 1.15$ & $14.9 \pm 0.65$ & $14.3 \pm 0.65$ & $17.2 \pm 0.95$ & $17.2 \pm 0.95$ & $4.9 \pm 0.10$ & $4.9 \pm 0.10$ & $79.0 \pm 0.59$ & $79.6 \pm 0.59$ \\
\hline Gewone Dai 3 Rial 10 & $50.9 \pm 1.50$ & $50.0 \pm 2.0$ & $30.4 \pm 0.67$ & $31.4 \pm 1.26$ & $34.3 \pm 0.95$ & $34.6 \pm 0.95$ & $6.4 \pm 2.5$ & $6.4 \pm 2.5$ & $81.5 \pm 0.66$ & $82.5 \pm 1.15$ \\
\hline Bravour & $22.8 \pm 1.51$ & $23.7 \pm 1.53$ & $15.7 \pm 0.46$ & $15.0 \pm 0.74$ & $22.2 \pm 1.10$ & $22.3 \pm 1.11$ & $5.0 \pm 0.12$ & $5.0 \pm 0.12$ & $76.6 \pm 0.42$ & $76.0 \pm 0.91$ \\
\hline
\end{tabular}

Table 2: Identified compounds of parsley genotypes from GC/MS.

\begin{tabular}{lcccccc}
\hline Compound name & CAS Number & $\mathbf{R}_{\mathbf{t}}^{*}$ & RRT** & Molecular formula & Molecular weight & Base peak \\
\hline $\boldsymbol{\alpha}$-Pinene & $80-56-8$ & 9.53 & 0.35 & $\mathrm{C}_{10} \mathrm{H}_{16}$ & 136 & 93 \\
$\boldsymbol{p}$-Cymene & $99-87-6$ & 11.70 & 0.43 & $\mathrm{C}_{10} \mathrm{H}_{14}$ & 134 & 119 \\
Myristicin & $607-91-0$ & 23.33 & 0.85 & $\mathrm{C}_{11} \mathrm{H}_{12} \mathrm{O}_{3}$ & 192 & 192 \\
Apiole & $523-80-8$ & 26.95 & 1.00 & $\mathrm{C}_{12} \mathrm{H}_{14} \mathrm{O}_{4}$ & 222 & 222 \\
\hline
\end{tabular}

*RT: Retention Time. **RRT: Relative Retention Time.

Table 3: The percentages of the identified compounds of parsley genotypes by GC/MS.

\begin{tabular}{lcccc}
\hline \multirow{2}{*}{ Compound name } & \multicolumn{4}{c}{ \% The identified compounds of Parsley genotypes } \\
\cline { 2 - 5 } & Moskrul 2 Petra & Moskrul 2 KRA USA & Gewone Dai 3 Rial 10 & Bravour \\
\hline $\boldsymbol{a}$-Pinene & 16.21 & 15.60 & 16.61 & 15.90 \\
$\boldsymbol{p}$-Cymene & 19.85 & 20.61 & 23.07 & 23.23 \\
Myristicin & 33.91 & 33.22 & 28.51 & 29.30 \\
Apiole & 3.22 & 3.52 & 3.20 & 3.49 \\
\hline
\end{tabular}




\section{References}

[1] Aćimovic MG. Nutraceutical Potential of Apiaceae. Bioactive Molecules in Food. 2017;1-31.

[2] Peter KV. Handbook of Herbs and Spices. Woodhead Publishing in Food Science and Technology, Volume 2, 2004.

[3] Bailey LH, Bailey EZ. A concise dictionary of plants cultivated in the United States and Canada. Hortus Third. $1^{\text {st }}$ Edn. 1976.

[4] Petropoulos SA, Daferera D, Akoumianakis CA, Passam HC, Polissiou MG. The effect of sowing date and growth stage on the essential oil composition of three types of parsley (Petroselinum crispum). Journal of the Science of Food and Agriculture. 2004;84:1606-10.

[5] Rasooli I, Mirmostafa A. Bacterial susceptibility to chemical composition of essential oils from Thymus kostschyanus and Thumus persicus. Journal of Agriculture and Food Chemistry. 2003;61:2200-5.

[6] Ali SE, El-Shaffey AA, Selim ME, El-massry KF, Sabry BA. Chemical profile, antioxidant, antifungal and antiaflatoxigenic activity of parsley and ginger volatile and non-volatile extracts. Journal of Biologically Active Products from Nature. 2011;1(1):81-96.

[7] Hassan AM, Abdel-Wahhab MA. Antioxidant effect of parsley and Panax ginseng extract standardized with ginsenosides $\mathrm{Rg} 3$ against alteration induced in reproductive functions in male mice. The Egyptian Journal of Hospital Medicine. 2006;22:60-72.

[8] AOAC; Official Methods of Analysis, 21st Edn. 2019, https://www.aoac.org/official-methods-of-analysis-21st-edition-2019/,

(Retrieved 02/12/2017).

[9] Singleton VL, Rossi JA. Colorimetry of total phenolics with phosphomolybdic phosphotungstic acid reagents. American Journal of Enology and Viticulture. 1965;16:144-58.

[10] NIST; National Institute of Standards and Technology; http://webbook.nist.gov/ (Retrieved 01/03/2019).

[11] Adams RP. Identification of essential oil components by Gas Chromatography/Mass Spectrometry. Edn. $4^{\text {th }}$, Illinois, USA, Allured books, 1989.

[12] El-Kashef DF, Hamed ANE, Khalil HE, Kamel MS. Investigation of the Unsaponifiable and Saponifiable Matters of Pachypodium lamerei Drake Leaves and Stems By GC/MS. Journal of Pharmacognosy and Phytochemistry. 2014;3(1C):128-32.

[13] Solanke OF, Awonorin SO. Kinetics of vitamin C degradation in some tropical green leafy vegetables during blanching. Nigerian Food Journal. 2002; 13:24-32.

[14] Ashaye OA. Effect of processing methods on chemical and consumer acceptability of kenaf and corchorus vegetables. Marsland Press Journal of American Science, 2010;6 (2):167-70.

[15] Lopez MG, Sancheze-Medoza IR, Ochoa-Alejo N. Comparative study of volatile components and fatty acids of plants and in vitro cultures of parsley (Petroselinum crispum) (Mill) nym ex hill). Journal of Agricultural Food Chemistry. 1999;47:3292-6.

[16] Nielsen SE, Young JF, Daneshvar B, Lauridsen ST, Knuthsen P, Sandstrom B. Effect of parsley intake on urinary apigenin excretion, blood antioxidant enzymes and biomarkers for oxidative stress in human subjects. British Journal of Nutrition. 1999;81:447-55.

[17] Ozturk Y, Baser CHK, Aydin S. Hepatoprotective (antihepatotoxic) plants in Turkey. Proceedings of the $9^{\text {th }}$ Symposium on Plant Drugs, Eskisehir, Turkey, May. 1991:40-50.

[18] Wong PYY, Kitts DD. Studies on the dual antioxidant and antibacterial properties of parsley (Petroselinum crispum) and cilantro (Coriandrum sativum) extracts. Food Chemistry. 2006;97:505-15.

[19] Baytop T. Therapy with Medicinal Plants in Turkey (Past and Present), Istanbul University Press, Istanbul. 1984.

[20] Kerydiyyeh SI, Uste J, Kaouk I, Al-Sadi R. The mechanism underlying the laxative properties of parsley extract. Phytomedicine. 2001;8:382-8.

[21] Manderfeld MM, Schafer HW, Davidson PM, Zottola EA. Isolation and identification of antimicrobial furocoumarins from parsley. Journal of Food Protection. 1997;60(1):72-7.

[22] Moustafa YMM, Abdelwahab M. Evaluation of four novel imported and Egyptian curly and non-curly leafed parsley genotypes for yield and essential oil composition under the Egyptian sandy soil growing conditions. Journal of Basic and Applied Research. 2016;2(3): 345-52.

[23] Osman YAH, Yaseen EM, Farag MM. Antimicrobial effect of some essential oils mixtures. Journal of Applied Sciences Research.2009;5(9):1265-76 [24] Zheng GQ, Kenney PM, Zhang J, Lam LK. Inhibition of benzo [a] pyreneinduced tumorigenesis by myristicin, a volatile aroma constituent of parsley leaf oil. Carcinogenesis. 1992;13(10):1921-23.

[25] Stefano VD, Pitonzo R, Schillaci D. Antimicrobial and antiproliferative activity of Athamanta sicula L. (Apiaceae). Pharmacognosy Magaine. 2011;7(25):31-4. 